\title{
BACCHARIS IBITIPOCENSIS (ASTERACEAE: ASTEREAE) A NEW SPECIES ENDEMIC FROM SERRA DE IBITIPOCA, MINAS GERAIS, BRAZIL ${ }^{1}$
}

\author{
LEONARDO PAZ DEBLE ${ }^{2}$
}

\begin{abstract}
Baccharis ibitipocensis, a new species of section Oblongifoliae DC. is described and illustrated. Comments about the new taxa and related species are also furnished.

Key words: Baccharis, new species, Oblongifoliae, Astereae, Asteraceae, Ibitipoca, Brazil.
\end{abstract}

\section{RESUMO}

[Baccharis ibitipocensis (Asteraceae:Astereae) uma nova espécie endêmica da Serra de Ibitipoca, Minas Gerais, Brasil].

Baccharis ibitipocensis, uma nova espécies da seção Oblongifoliae DC. é descrita e ilustrada. Comentários sobre o novo táxon e espécies relacionadas são também fornecidos.

Palavras-chave: Baccharis, espécie nova, Oblongifoliae, Astereae, Asteraceae, Ibitipoca.

\section{INTRODUCTION}

During the review of Baccharis sect. Oblongifoliae from Brazil (Deble et OliveiraDeble, unpublished) some unusual exsiccates collected in "Serra de Ibitipoca", Minas Gerais state (Brazil), were analyzed by me. This material was previously determined as $B$. brachylaenoides (Barroso, in exsiccate), B. venosa (Oliveira et al., 2006) or B. oblongifolia (Borges \& Forzza, 2008), but the analysis of collections (includes types) of these species and other species allied led to interpret the material of "Serra de Ibitipoca" as a different species, presently recognized as new.

\section{RESULTS}

Baccharis ibitipocensis Deble, sp. nov.

Baccharis oblongifolia auct. non (Ruiz \& Pav.) Persoon, in Borges et Forzza, Boletim de Botânica da Universidade de São Paulo 26 (2): 144. 2008.

Baccharis venulosa auct. non DC., in Oliveira et al., Balduinia 9: 26. 2006.

\footnotetext{
${ }^{1}$ Recebido em 15-12-2008 e aceito para publicação em 02-02-2009.

2 Biólogo, Dr., deble.biol@gmail.com
}

A Baccharis oblongifoliae sensu lato (B. brachylaenoidi, $B$. venulosae et $B$. maguirreanae inclusi) folia oblanceolata capitula in panicula corymbosa vel pyramidata disposita similis sed folia cartacea ad coriacea (vs. papiracea), conspicua retinervia (vs. peninervia vel rare inconspicua retinervia), nitido vernicosa (vs. opaca), setis pappi flores feminei rufescenti, ondulati, non acrescenti (vs. nitidi albi, rare lutei, acrescenti), optime distincta. A Bacharis ligustrinae, cui affinis, folia obovata ad oblanceolata (vs. oblonga), utrinque nitido vernicosa (vs. opaca), apice leviter acuta ad obtusa (vs. rotundata), differt. A Baccharis meridensi, cui maxime proxima, folia $3.2-7.6 \mathrm{~cm}$ longa, $0.9-2.2 \mathrm{~cm}$ lata (vs. 0.9-4.7 cm longa, 0.7-2.4 cm lata), laminis obovatis ad oblanceolatis (vs. late ellipticis ad obovato spathulatis), apice leviter acutis ad obtusis (vs. obtusis ad rotundatis), differt.

Suffrutex 1 m altus; caules pauci ramosis, erectis, apice rufescenti-tomentosis, base glabrescentis. Folia obovata ad oblanceolata, 3.2-6.5 cm longa, 1$2.1 \mathrm{~cm}$ lata, alterna, retinervia, glabra, nitida, leviter discolora; laminis cartaceis ad coriaceis, utrinque conspicua retinervis, nitidis, integris, revolutis, supra nigro castaneis, subtus castaneis, apice leviter acutis ad obtusis, mucronatis, base in petiolis attenuatis; petiolis rufescenti-castaneis, glabrescentis, 0.4-0.8 mm. Capitula (brevi) pedicellata in 2-3 dense panicula corymbosa terminalibus disposita. Capitula feminea 5.5-7 mm alta, 3.5-5.5 mm lata. Involucrum 3-4.2 mm altum, 3-4.5 mm latum, 12-14 florum. Bracteis involucri 3- 
4 seriatis, margem hyalinis, fimbriatis, conspersis pilosis; externis ovatis ad obovato-oblongis, 1.8-3 mm longis, 1.1-1.5 mm latis; mediis, late oblongis ad oblongis 3-3.8 mm longis, 1-1.5 mm latis; intimis oblanceolatis 3.8-4.2 mm longis, $0.8-1 \mathrm{~mm}$ latis. Clinanthium cum caducis bracteis munitum. Bracteis clinanthii 4-10, linear-oblanceolatis ad linearlanceolatis, 4-5.3 mm longis, 0.4-0.8 mm latis. Flores feminei corolla tubulosa, 2.6-3 mm longa, apice 5-dentata. Stylo exserto, 3-4 mm longo; rami styli 0.5-0.7 mm longi. Pappus 2.6-3.5 mm longus; setis pappi 42-54. Cypsela cylindrica, 1.3-1.9 mm longa, castanea, 4-6 costata, apex cum pauci pilis geminis vestitis.

Typus: Brazil, Minas Gerais "Serra de Ibitipoca, entre 1.550-1.630 m.s.m., arbusto até $1 \mathrm{~m}$ de altura, crescendo na beira das matas; capítulos alvos, ?, 30.IX.1970", D. Sucre 7.210, Pe. L. Krieger, P. I. S. Braga. Holotypus MBM 119.000! Isotypi RB 167.220! NY 00847039.

The measures below include all material examined:

Subshrub 0.8-1.8 m high; stems erect, branching in the distal third; young shoots reddish brown, dense ferruginous tomentose, older shoots darker, glabrescent. Leaves obovate to oblanceolate, $3.2-7.6 \mathrm{~cm}$ long, $0.9-2.2 \mathrm{~cm}$ wide, spirally alternate, reticulum veined, slightly discolors, adaxially dark brown, abaxially brownish, margin entire and revolute, apex acute to obtuse, mucronate, base attenuate in petiole; leaf blades cartaceous to coriaceous, strongly resinous, prominent reticulum veined and bright intensely in both surfaces; petioles 0.2-0.8 mm, reddish brown, indument usually covered by resin. Capitulescence arranged in 13 dense terminal corymbiform panicles, $5-8 \mathrm{~cm}$ long and wide, with 58-193 capitulas, that together appearing a panicle corymbiform or pyramidal with $5-14 \mathrm{~cm}$ long, $5-13 \mathrm{~cm}$ wide, sometimes with more than 400 capitulas. Capitula (shortly) pedunculate; peduncles reddish brown, dense tomentose, up to $12 \mathrm{~mm}$ long; bracts $1-2$, lanceolate, up to $2.8 \mathrm{~mm}$ long. Female capitula 5.5-7 mm long, 3.5-5.5 mm wide. Involucre 3-4.2 $\mathrm{mm}$ long, 3-4.5 mm wide. Involucral bracts in 3-4 series, margin hyaline, fimbriate, with few uniseriate trichomes, centrally reddish brown, glabrous. Outer bracts ovate to obovate-oblong, 1.8-3 mm long, 1.1$1.5 \mathrm{~mm}$ wide. Mediam bracts, broadly oblong to oblong 3-3.8 mm long, 1-1.5 mm wide. Inner bracts oblanceolate $3.8-4.2 \mathrm{~mm}$ long, 0.8-1 mm wide. Clinanthium with deciduous bracts; clinanthium bracts $4-10$, linear-oblanceolate to linear-lanceolate, 4-5.3 mm long, 0.4-0.8 mm wide. Female flowers 8-16. Corolla 2.6-3.1 mm long, apically short 5-dentate, with scattered trichomes. Style exceeding the corolla, 3-4 mm long, branches 0.5-0.7 mm long. Pappus 2.6-3.9 mm long; bristles 42-54. Cypsela cylindrical, 1.3-1.9 mm long, light brown, 4-6 ribbed, with few twin hairs at apex concentrate. Male capitula broadly campanulate 4.5-5.5 mm long and wide. Involucre $2.4-3.3 \mathrm{~mm}$ long, $3.5-4.3 \mathrm{~mm}$ wide. Involucral bracts in 3 series, margin hyaline, fimbriate, with scattered uniseriate trichomes, centrally reddish brown, with few trichomes in outermost and glabrous in the innermost bracts. Outer bracts ovate to obovate, 1.5-2.2 mm long, 0.9-1.2 mm wide. Median bracts broadly elliptic to broadly oblong, 2.2-3 $\mathrm{mm}$ long, 0.9-1.1 mm wide. Inner bracts oblongs to oblanceolate, $2.8-3.2 \mathrm{~mm}$ long, 0.7-0.9 mm wide. Clinanthium conical, glabrous. Male flowers 17-24. Corolla 2.4-3.1 mm long. Style exceeding the corolla, 3.2-3.9 $\mathrm{mm}$ long, branches 0.4-0.5 mm. Anthers 1-1.2 mm long. Pappus 2.5-3 mm long; bristles 16-25. Abortive cypsela obconical, 0.15-0.25 mm long, with few trichomes at apex.

Distribution \& habitat: Baccharis ibitipocensis is endemic of the "Serra de Ibitipoca", in southeast of Minas Gerais, in Santa Rita do Ibitipoca and Lima Duarte cities. The new species is found in "campos rupestres", at altitudes between $1.450-1.630 \mathrm{~m}$. 


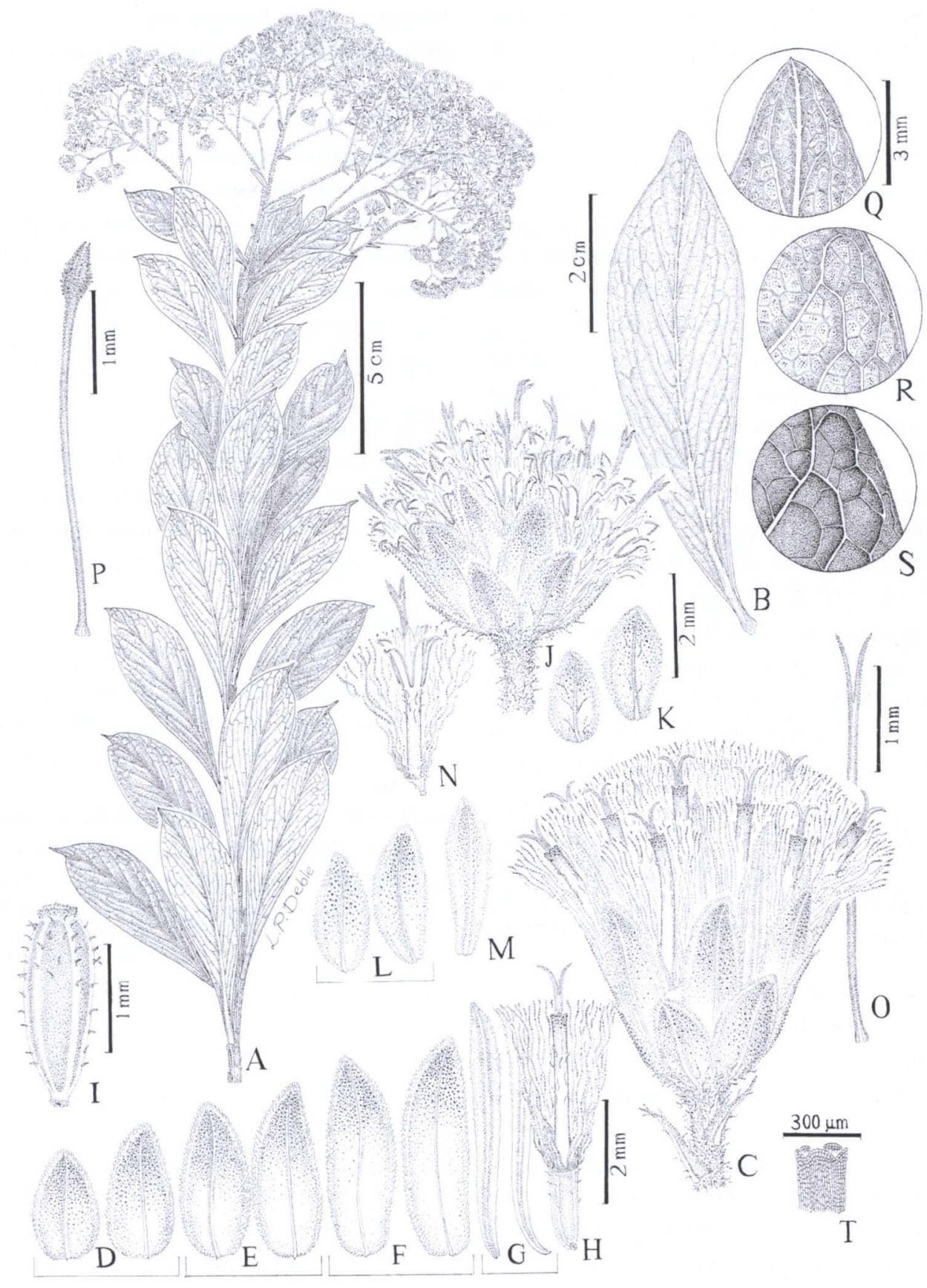

FIGURE 1 - Baccharis ibitipocensis Deble. Female branch (A). Leaf (B). Female capitulum (C). Female bracts: outer (D), median (E), inner (F). Clinanthium bracts $(\mathrm{G})$. Female flower $(\mathrm{H})$. Cypsela (I). Male capitulum (J). Male bracts: outer (K), median (L), inner (M). Male flower (N). Female flower style (O). Male flower style (P). Leaf detail: apex (Q), margin abaxial surface (R), margin adaxial surface (S). A-J, O, Q-S of Sucre 7.210. K-N, P of Magalhães 449. 
Specimina visa (paratypi): Brazil, Minas Gerais, Serra de Ibitipoca, entre pedras na margem do Ribeirão do Salto, arbusto, $1 \mathrm{~m}$, ?, 13.IX.1940, M. Magalhães 449 (SP); Serra de Ibitipoca, Pico do Peão, heliófita em formação de arenito, 1.450-1.580 m s.m., ?, 28.IX.1970, P. I. S. Braga 1.891 (R, MBM).

Comments: Baccharis ibitipocensis is recognized by prominent reticulum veined, strongly resinous and intensely bright leaves, as well as by capitulescence born in 1-3 dense terminal corymbiform panicles, that together appearing a corymbiform or pyramidal panicle, with 5-14 cm long, 5-13 cm wide, sometimes with more than 400 capitulas. These morphological characteristics are important to the separation from B. oblongifolia (includes $B$. brachylaenoides DC., $B$. venulosa DC. and $B$. maguireana Malag.), that show pinnately leaves veined with 5-12 pairs of major lateral veins, inconspicuous in adaxial surface, rarely conspicuous in extra brazilian material, but never strongly resinous and intensely bright in both surfaces. The capitulescence is much variable in B. oblongifolia, but in brazilian material usually born in terminal broadly pyramidal panicles with measures up to the cited in $B$. ibitipocensis.
The alopatric species Baccharis meridensis Steyerm. (here recognized as separated of $B$. oblongifolia) is nearly related with $B$. ibitipocensis; both species showed cartaceous to coriaceous, prominent reticulum veined and resinous leaves, as well as capitulescence born in dense terminal corymbiform panicles; however, the leaves of $B$. meridensis are elliptic to obovate-spathulate with $0.9-4.7 \mathrm{~cm}$ long, 0.7 $2.4 \mathrm{~cm}$ wide (vs. obovate to oblanceolate, 3.2$7.6 \mathrm{~cm}$ long, $0.9-2.2 \mathrm{~cm}$ wide), with apex rounded (vs. slightly acute to obtuse).

\section{ACKNOWLEDGMENTS}

The author is indebted to José Newton Cardoso Marchiori and Anabela Silveira de Oliveira Deble for helpful comments and to an anonymous referee for review of the manuscript.

\section{REFERENCES}

BORGES, R., FORZZA, R. A tribo Astereae (Asteraceae) no Parque Estadual de Ibitipoca, Minas Gerais, Brasil. Boletim Botânica da Universidade de São Paulo, v. 26, n.2, p.131-154. 2008.

OLIVEIRA, A. S. de, DEBLE, L. P., SCHNEIDER, A. A., MARCHIORI, J. N. C. Checklist do gênero Baccharis para o Brasil (AsteraceaeAstereae). Balduinia, Santa Maria, n. 9, p.1727, 2006. 